\title{
Evaluation of methods for long term storage of the boysenberry downy mildew pathogen Peronospora sparsa
}

\author{
A.M. Herath Mudiyanselage ${ }^{1}$, M.V. Jaspers ${ }^{1}$, H.J. Ridgway ${ }^{1}$, M. Walter ${ }^{2}$, G.I. \\ Langford $^{3}$ and E.E. Jones ${ }^{1}$ \\ ${ }^{1}$ Faculty of Agriculture E Life Sciences, Lincoln University, Lincoln 7647, Christchurch, \\ New Zealand \\ ${ }^{2}$ Plant \& Food Research, Old Mill RD, RD3, Motueka, 7198, New Zealand \\ ${ }^{3}$ Berryworld Ltd, Tai Tapu, RD 2, Christchurch, New Zealand \\ Corresponding author: Anusara.HerathMudiyanselage@lincolnuni.ac.nz
}

\begin{abstract}
Downy mildew of boysenberry is caused by the biotrophic pathogen Peronospora sparsa. To ensure supplies of viable spore inoculum for infection experiments, six storage methods were assessed: the leaf discs cut from sporulating areas of the leaf stored dry or in $20 \%$ glycerol, and spores were suspended in $20 \%$ glycerol, all three of which were stored at either $-20^{\circ} \mathrm{C}$ or $-80^{\circ} \mathrm{C}$. After $1,2,4$ or 6 months storage, spore viability and the capability to infect leaf discs were evaluated. Storage methods had no significant effects on spore germination or infection. Storage time and temperature significantly $(\mathrm{P}<0.001)$ affected spore viability and infection, being greatest after 1 month and at $-80^{\circ} \mathrm{C}$. Overall, viability of spores stored as suspensions at $-80^{\circ} \mathrm{C}$ (the most effective treatment) was greater than all other methods tested, and spore germination decreased from over $60 \%$ after 1 month of storage to less than $5 \%$ after 4 months.
\end{abstract}

Keywords storage temperature, spore germination, infection, sporulating, dryberry.

\section{INTRODUCTION}

Downy mildew of Rubus and Rosa species is caused by Peronospora sparsa Berk. (synonym P. rubi Rabenh.) (Breese et al. 1994), and is considered the most economically important disease of boysenberry (Rubus spp.) (Ellis et al. 1991). This disease is a serious threat to boysenberry growers in New Zealand. In 2001/02 in the Nelson region, downy mildew on fruit reduced boysenberry yields by approximately $50 \%$ for crops grown under conventional management (Richards 2002), with total losses in 2002 valued at NZ\$1.8 M (Dodd et al. 2007). For organic growers, the situation was worse, with a total loss of fruit for that season. More recently in Whakatane, downy mildew was estimated to reduce yields by up to $25 \%$ in 2009-2010 (C.I. Julian, Berry Devine Boysenberries, Whakatane, personal communication).

Peronospora sparsa is an obligate biotroph, and as such is difficult to maintain in the laboratory as it cannot be cultured on artificial media. Maintenance of the pathogen requires culturing on plants, which is both time- and space-consuming, and is difficult during plant dormancy over winter periods. A long term storage method is therefore required to ensure viable spore inoculum is available for infection studies. Breese et al. (1994) reported that 
P. sparsa isolates from Rosa and Rubus spp. when stored on freshly sporulating leaf disks or leaflets in sealed plastic boxes at $-70^{\circ} \mathrm{C}$, remained viable for up to 4 months, but longer storage was not reported. In addition, they also reported that $P$. sparsa viability was retained when sporulating leaf discs were stored in liquid nitrogen, but not the maximum storage time. For the related pathogen $P$. viciae, spores on sporulating pea leaves were reported to remain viable for at least 1 year when stored dry at $-80^{\circ} \mathrm{C}$ (Gill \& Davidson 2005). Glycerol has been widely used as a cryopreservation protectant for different microorganisms including oomycetes (Hubálek 2003). This compound maintained viability of $P$. parasitica spores to $21 \%$ after 1 year of storage (Klodt-Bussmann \& Paul 1995). In contrast, for $P$. viciae, spores were not viable after 45 days when stored on different cryoprotectants including glycerol, skim milk plus glycerol or dimethylsulfoxide (Gill \& Davidson 2005).

The aim of the present study was to evaluate different methods for long term storage of $P$. sparsa spore inoculum with or without a cryoprotectant $(20 \%$ glycerol), to provide information on effective storage protocols for this pathogen.

\section{MATERIALS AND METHODS}

Six storage methods were assessed. Leaves obtained from boysenberry (cv. 'Mapua') plants systemically infected by $P$. sparsa and grown in the Lincoln University shadehouse were used as a source of the pathogen inoculum. In order to produce sufficient young spores, 400-500 systemically infected leaves were incubated on $1.5 \%(\mathrm{w} / \mathrm{v})$ water agar (WA) at $15^{\circ} \mathrm{C}$ in $12: 12 \mathrm{~h}$ light:dark, and observed for sporulation under the stereomicroscope. The resulting spores were stored in the following ways:

1. The sporulating regions of leaves were cut aseptically as leaf discs ( $7 \mathrm{~mm}$ diameter), and six leaf discs were placed in each sterile vial and stored at $-80^{\circ} \mathrm{C}$ or $-20^{\circ} \mathrm{C}$

2. The sporulating leaf discs were placed in sterile vials containing $20 \%$ glycerol, mixed for $5-10 \mathrm{~s}$ and stored at $-80^{\circ} \mathrm{C}$ or $-20^{\circ} \mathrm{C}$.

3. Spores were harvested from sporulating lesions by gently shaking sporulating leaf discs in $20 \%$ glycerol. Any leaf debris was removed using sterilised forceps and the concentration (assessed with a hemacytometer) was adjusted to $10^{5}$ spores $/ \mathrm{ml}$ with $20 \%$ glycerol. The final glycerol suspensions were pipetted into $1.7 \mathrm{ml}$ cryogenic tubes and stored at either $-80^{\circ} \mathrm{C}$ or $-20^{\circ} \mathrm{C}$.

Three vials were prepared for each of the six storage regimes for each storage time period (1, 2,4 or 6 months).

The viability of spores was determined after each storage time period using three randomly selected vials from each treatment. The leaf discs were placed in sterile water, gently shaken and the spore concentrations in the resulting suspensions were adjusted to $10^{4} \mathrm{spore} / \mathrm{ml}$ based on haemocytometer counts. The stored spore suspensions were diluted with sterile distilled water to $10^{4} \mathrm{spores} / \mathrm{ml}$. To assess germination and infection, fresh leaf discs that had been washed with sterile water (Herath Mudiyanselage et al. 2012) to minimise contamination were placed on $1.5 \%$ WA, abaxial side uppermost. For each replicate spore suspension for each treatment, a $20 \mu \mathrm{l}$ drop (approximately 200 spores) was placed on the abaxial surface of each of two separate leaf discs and incubated in the dark at $20^{\circ} \mathrm{C}$ for $24 \mathrm{~h}$. Germination was assessed using a cellotape strip to pick up these spores and mounting them on a drop of lacto-glycerol cotton blue placed on a microscopic slide (best method from preliminary experiments). A spore was assessed as germinated when the germ tube length was at least half the diameter of the spore. For each sample, the total intact spores and numbers of germinated spores were counted using a light microscope at $\times 10$ magnification.

To assess the infective capacity of the spores, a $20 \mu \mathrm{l}$ drop of each replicate diluted spore suspension, was placed on the surface of each of three sterile water washed leaf discs placed on $1.5 \%$ WA and incubated at $15^{\circ} \mathrm{C}$ in $12: 12 \mathrm{~h}$ light:dark, the optimum conditions for infection determined in preliminary studies. The presence of lesions was assessed after 14 and 24 days incubation. The experiments were repeated three times for the germination assessments and twice for the infection assessments. 


\section{Statistical analyses}

The percentage of healthy spores and percentage germination for the different storage treatments after different storage times were analysed using general linear model (Minitab 16). When factors were statistically significant, means were compared between treatments using Tukey's honestly significant differences (HSDs) at $\mathrm{P}<0.001$. The proportions of leaf discs infected and with lesions were assessed by generalized linear model in GenStat 14. Confidence intervals (95\%) for binomial proportion means are indicated in Figure 1. The experimental repeats were included in the analyses as random factors.

\section{RESULTS}

There was no statistically significant effect of storage method $(\mathrm{P}=0.111$; Table 1$)$ on spore germination. Storage time $(\mathrm{P}<0.001)$ affected spore viability, being greater after 1 month storage than after longer storage times. The storage temperature also affected spore germination $(\mathrm{P}<0.001)$, with spore viability being greater after storage at $-80^{\circ} \mathrm{C}$ than at $-20^{\circ} \mathrm{C}$. The interaction between the storage methods and temperatures $(\mathrm{P}=0.006)$, and time and temperatures $(\mathrm{P}=0.004)$ also significantly affected the viability of spores. After 1 month, storage viability was significantly higher
$(\mathrm{P}<0.001)$ at $-80^{\circ} \mathrm{C}(53.3 \%)$ than $-20^{\circ} \mathrm{C}(41.6 \%)$. Viability of spores stored as a suspension at $-80^{\circ} \mathrm{C}(22.8 \%)$ was significantly higher $(\mathrm{P}<0.001)$ than all other methods $(16.5-12.5 \%)$. However, even in the most effective treatment (spore suspension at $-80^{\circ} \mathrm{C}$ ) spore germination decreased from over $60 \%$ after 1 month storage to below $5 \%$ after 4 months storage.

There was no statistically significant effect of storage method $(\mathrm{P}=0.464$; Figure 1$)$ on ability of the spores to subsequently infect and cause leaf lesions. The ability of the spores to infect was affected both by storage time $(\mathrm{P}<0.001)$ and temperature $(\mathrm{P}<0.001)$. The interaction between the storage method and temperature $(\mathrm{P}=0.013)$ also significantly affected infection. After 1 month storage, spores stored as suspensions or on dried leaf discs at $-80^{\circ} \mathrm{C}$ gave greater levels of infection compared with spores stored as dry leaf discs or in glycerol at $-20^{\circ} \mathrm{C} \quad(\mathrm{P}<0.001)$. There were no significant differences in the amounts of infection between the three storage methods at $-80^{\circ} \mathrm{C}$ and spores suspended in glycerol at $-20^{\circ} \mathrm{C}$. Decreased infection occurred between 1 and 2 months storage for all storage treatments, except for leaf discs stored in glycerol at $-80^{\circ} \mathrm{C}$ and $-20^{\circ} \mathrm{C}$, and dried leaf discs at $-20^{\circ} \mathrm{C}$. There were very low infection rates observed from spores after

Table 1 Mean percent germination of Peronospoa sparsa spores after different storage periods at -80 or $-20^{\circ} \mathrm{C}$ for different storage methods: spores were suspended (SS) in $20 \%$ glycerol, leaf discs cut from sporulating regions were stored either dry (LD) or in $20 \%$ glycerol.

\begin{tabular}{|c|c|c|c|c|c|c|c|c|}
\hline \multirow[b]{2}{*}{ Months } & \multicolumn{3}{|c|}{$-80^{\circ} \mathrm{C}$} & \multicolumn{3}{|c|}{$-20^{\circ} \mathrm{C}$} & \multicolumn{2}{|c|}{ Temperature $\times$ time $^{1}$} \\
\hline & $\begin{array}{c}\text { SS in } 20 \% \\
\text { glycerol }\end{array}$ & $\mathrm{LD}$ & $\begin{array}{c}\text { LD in } 20 \% \\
\text { glycerol }\end{array}$ & $\begin{array}{c}\text { SS in } \\
20 \% \\
\text { glycerol }\end{array}$ & LD & $\begin{array}{c}\text { LD in } \\
20 \% \\
\text { glycerol }\end{array}$ & $-80^{\circ} \mathrm{C}$ & $-20^{\circ} \mathrm{C}$ \\
\hline 1 & 61.5 & 47.6 & 50.8 & 44.3 & 40.8 & 39.6 & $53.3 \mathrm{a}$ & $41.6 \mathrm{~b}$ \\
\hline 2 & 22.0 & 13.2 & 13.3 & 4.3 & 12.6 & 14.6 & $16.2 \mathrm{c}$ & $10.5 \mathrm{c}$ \\
\hline 4 & 5.0 & 1.2 & 0.7 & 0.9 & 1.1 & 0.7 & $2.3 \mathrm{~d}$ & $0.9 \mathrm{~d}$ \\
\hline 6 & 2.6 & 1.2 & 1.2 & 0.4 & 0.5 & 1.5 & $1.7 \mathrm{~d}$ & $0.8 \mathrm{~d}$ \\
\hline
\end{tabular}

Temperature $\times$ method

$\begin{array}{llllll}22.8 \mathrm{~A} & 16.5 \mathrm{~B} & 15.8 \mathrm{~B} & 12.5 \mathrm{~B} & 13.7 \mathrm{~B} & 14.1 \mathrm{~B}\end{array}$

${ }^{1}$ Values followed by the same letter are not significantly different. For temperature $\times$ method $(\mathrm{A}-\mathrm{B})$ and temperature $\times$ time $(\mathrm{a}-\mathrm{d})$, differences between means were highly significant $(\mathrm{P}=0.006, \mathrm{P}=0.004$, respectively). Means within a column followed by the same letters are not significantly different according to Tukey's HSD at $\mathrm{P}<0.001$ 


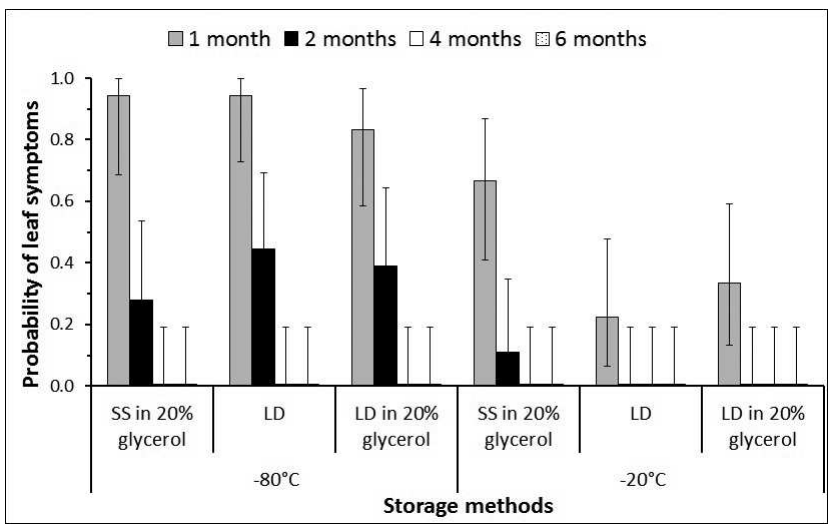

Figure 1 Probability of lesions (infection) on leaf discs (LD), resulting from Peronospora sparsa spores stored for different periods at either -80 or $-20^{\circ} \mathrm{C}$, using three different storage methods: leaf discs cut from sporulating regions stored dry (LD), leaf discs in 20\% glycerol or spores suspended (SS) in 20\% glycerol. Error bars represent the 95\% confidence intervals of the probability of lesions (infection).

3 months storage for all storage methods and temperatures, and no infection resulted from spores stored for 4 or 6 months.

In addition, after 6 months spores stored on dried leaf discs at both temperatures were distorted and shrunken compared with the healthy spherical appearance of the spores stored as either suspensions or leaf discs in glycerol.

\section{DISCUSSION}

Spore viability of $P$. sparsa decreased with increasing storage time over 1 month, with none of the storage methods tested resulting in the maintenance of spore viability and ability of the spores to infect boysenberry leaves beyond 2 month storage. After 1 month storage, the viability of spores stored at $-80^{\circ} \mathrm{C}$ was greater than those stored at $-20^{\circ} \mathrm{C}$, but this was not maintained after 2 months storage. In contrast, Breese et al. (1994) reported that P. sparsa, both from Rubus (blackberry and tummelberry) and Rosa species, retained viability for 1-4 months when stored as sporulating leaf discs or leaflets in a sealed plastic box at $-70^{\circ} \mathrm{C}$. However, no information regarding the relative viability of the spores after the different storage periods was provided. Long-term storage of P. sparsa spores suspended in dimethylsulphoxide by cryopreservation using liquid nitrogen was also reported by these authors, but again no information on the viability after different storage periods was provided. In addition, this method required specialised equipment to enable the temperature to be lowered at a controlled rate. Peronospora viciae spores stored dry as sporulating infected pea leaves at $-80^{\circ} \mathrm{C}$ retained viability for at least 1 year (Gill \& Davidson 2005), infecting approximately 62\% of pea seedlings compared with $93 \%$ seedling infection when fresh spores were used. However, these authors also suggested that sufficient spores should be stored to compensate for the decrease in infection rate. In contrast spores suspended in dimethylsulphoxide, glycerol, glycerol and skim milk or in sterilised water and stored at $-80^{\circ} \mathrm{C}$ did not remain viable. However, in the present study with P. sparsa, the addition of glycerol did not significantly affect spore viability, indicating that different methods may be effective for different species of downy mildew pathogens.

It has been suggested that the sporangia (spores) of Peronosporales are relatively susceptible to damage and therefore lose viability due to their relatively thin and fragile walls (Laviola et al. 2006). Gulya et al. (1993) reported variable success of storage methods for different downy mildew species, with the spores of some species having extremely thin walls making them difficult to store. In this study, the shaking (mixing) and pipetting of the spores or osmotic shock due to the use of $20 \%$ glycerol (Laviola et al. 2006) may have contributed to the loss of viability due the physiological or mechanical stresses caused. However, the observation that the spores stored without the addition of glycerol were misshapen indicates that these spores were damaged during storage at low temperature. The addition of glycerol may also have protected the spores as it can penetrate cell walls and membranes as a cryoprotective additive even though the 
permeability is slow (Hubálek 2003). In the present study the leaf discs were not dried prior to storage, and this may have contributed to loss of viability, as Gill \& Davidson (2005) recommended including filter paper to prevent condensation or ice formation, which could contribute to a reduction in spore viability. Since $P$. sparsa also produces thick walled oospores, the use of oospores for long term storage may be effective and warrants testing. However, a suitable method for consistent and rapid production of oospores of P. sparsa is required.

The relationship between spore viability and ability of the spores to infect and cause visible leaf lesions was expected. Previous work had indicated that at least 20 spores were required to initiate infection and produce a lesion (A.M. Herath Mudiyanselage, unpublished data). Therefore the numbers of lesions that developed during the assessment period were probably proportional to the numbers of viable spores applied to the leaf discs. However, there was an indication that some viable spores had reduced capacity for infection. The spores stored as sporulating leaf discs both dry and in glycerol at $-20^{\circ} \mathrm{C}$ retained reasonable viability (approx. 40\%) after 1 month storage. However, these spores were not as effective for infecting the boysenberry leaves, since spores with reduced viability (13-4.3\%), such as those stored as leaf discs at $-80^{\circ} \mathrm{C}$ after 2 months, resulted in comparable infection. Likewise, although viability of spores stored for 2 months on leaf discs at $-20^{\circ} \mathrm{C}$ was similar to those stored at $-80^{\circ} \mathrm{C}$, resulting infection was much less from those spores stored at $-20^{\circ} \mathrm{C}$.

None of the methods used resulted in longterm storage of P. sparsa, with infection being low after only 1 month storage.

\section{ACKNOWLEDGEMENTS}

This research was funded by the New Zealand Ministry of Science and Innovation, and the Boysenberry Council Ltd. New Zealand boysenberry growers gave valuable support. Dr Simon Hodge, Lincoln University, gave valuable statistical advice.

\section{REFERENCES}

Breese WA, Shattock RC, Williamson B, Hackett C 1994. In vitro spore germination and infection of cultivars of Rubus and Rosa by downy mildews from both hosts. Annals of Applied Biology 125: 73-85.

Dodd SL, Boyd-Wilson K, Shanmuganathan D, Walter M 2007. The use of a PCR diagnostic test to predict and control Peronospora sparsa, downy mildew of boysenberry. New Zealand Plant Protection 60: 306 (Abstract only).

Ellis MA, Converse RH, Williams RN, Williamson B 1991. Compendium of raspberry and blackberry diseases and insects (Second printing ed.). APS Press, The American Phytopathological Society, St. Paul, USA.

Gill T, Davidson J 2005. A preservation method for Peronospora viciae conidia. Australasian Plant Pathology 34: 259-260.

Gulya TJ, Masirevic S, Thomas CE 1993. Preservation of air-dried downy mildew sporangia in liquid nitrogen without cryoprotectants or controlled freezing. Mycological Research 97: 240-244.

Herath Mudiyanselage AM, Jaspers MV, Ridgway HJ, Walter M, Langford GI, Jones EE 2012. Evaluation of methods for sterilising boysenberry leaves for downy mildew infection studies. New Zealand Plant Protection 65: 297 (Abstract only).

Hubálek Z 2003. Protectants used in the cryopreservation of microorganisms. Cryobiology 46: 205-229.

Klodt-Bussmann E, Paul VH 1995. Results on preservation and aggressiveness of Peronospora parasitica and results with regard to the disease reistance of the pathogen on winter oilseed rape. Journal of Phytopathology 143: 613-617 (Abstract only).

Laviola C, Cannizzaro G, Conigliaro G, Burruano S 2006. Simple techniques for long-term storage of Plasmopara viticola. Phytopathologia Mediterranea 45: 271-275.

Richards C 2002. Organic control of downy mildew in boysenberries-SSF Project Summary [SFF Project Summary]. http:// maxa.maf.govt.nz/sff/about-projects/search/ L02-017/index.htm (accessed October 2011) 